\title{
USING TECHNOLOGY OF OPEN SPACE AS ONE OF THE INNOVATIVE METHODS OF ACTIVE LEARNING IN THE TRAINING OF TECHNICAL SPECIALITIES
}

\section{Dembitska S. V., Kuzmenko O. S.}

\section{INTRODUCTION}

Modern world development contributes to the acceleration of reforms in higher education, changing the attitude of society as a whole and each citizen in particular to the place and role of education. Requirements for the quality of education are constantly updated, in particular, recently they have included such as student's motivation to learn, critical analysis of the material, development of self-educational competence, the formation of the ability to constantly improve their professional level and more.

These trends in higher education require the introduction of modern teaching disciplines, the use of the latest methods of teaching material, development and improvement of forms and methods of the educational process, which, in turn, will lead to qualitative changes in the entire educational process.

Accordingly, there is a need to find and implement modern forms and methods of teaching that will not only provide the desired result but also allow students to think creatively, make the right decisions in any professional situation.

The use of active learning methods in higher education is due to the fact that the vector of training of young people has shifted from the acquisition of knowledge and formation of professional skills for the development of competence, creative and communicative abilities, personal approach to solving the problem. In this context, the effectiveness of the use of active learning methods today is undeniable, because the acquisition of knowledge and skills through the intensification of educational and cognitive activities is more effective.

Also, the development of modern information technology allows to diversify learning through the use of computer programs, which allows to positively influence the development of spatial thinking, the ability to analyze, compare and more. Internet technologies provide the ability to obtain information from anywhere in the world. Biseds, it allows you to automate the assessment of student achievement, reducing the time spent by the teacher. At the same time, active learning methods allow you to learn 
how to manage the flow of information, its critical analysis and effective communication with each other.

There are many methods of active learning, and the emergence of new or modification of existing ones is regulated only by the imagination and desire of teachers. In this paper, an attempt is made to adapt the technologies of the Open Space for use in the training of future specialists in technical specialties in higher education institutions.

The work aims to study the possibility of using Open Space Technology in the process of training specialists in technical specialties, as well as to find conditions for its implementation in the educational process of higher education institutions.

The formulated goal involves solving several specific tasks, namely:

1) analysis of theoretical aspects of the use of active learning methods in the process of professional training of future specialists in technical specialties;

2) to substantiate the possibility and expediency of adaptation of Open Space technology in institutions of higher education of technical profile;

3 ) to determine the conditions and features of the use of Open Space technology in the process of training specialists in technical specialties;

4) to conduct a chamber pedagogical experiment to confirm the effectiveness of the use of Open Space technology in the process of professional training of future specialists in technical specialties.

To achieve the set goal and fulfill the outlined tasks of the research, scientific and methodological publications on the research problem were analyzed, the available practical developments and own pedagogical experience were generalized. The problems which arose during the organization of scientific work of students during all term of study in institutions of higher education by carrying out interrogation of teachers, students were analyzed. The reports of the methodical commissions of the university were studied, which were compiled based on the results of the analysis of the student's performance of course and qualification works. A chamber pedagogical university was held to determine the effectiveness of the proposed innovations based on certain indicators of scientific work of students.

To achieve this goal, use the following general research methods: abstraction, generalization, comparison and systematization. Methods of mathematical statistics were used to process the survey results.

\section{Theoretical aspects of the use of Open Space technology in higher education institutions}

The rapid development of machinery and technology, the constant change of production conditions, the renewal of technology requires the 
educational industry to respond appropriately and train competent specialists in technical specialities. After all, in today's labour market there is a demand for workers who have not only sufficient training but also the ability to selfeducation and self-improvement during professional activities. At the same time, they must be ready to make professional decisions taking into account all labour protection aspects and in unpredictable production conditions.

Also, the conditions of rapid informatization of production one of the main tasks of the modern educational process of higher education are the development of intellectual abilities, motivation and preparation for independent work with information flow, development of critical thinking and creative abilities of future technical specialists. In this context, we agree with the opinion of G. Raikovska that «among other important requirements for engineering education, we can note its continuous and advanced nature about existing science-intensive technologies, as well as the ability to respond flexibly to external environmental influences, providing a highquality world level of training» ${ }^{1}$.

To provide professional training of future specialists in technical specialities with these qualities is possible only through the introduction of active teaching methods in the educational process of higher education. After all, as noted by V. Yagupov, the characteristic didactic features of active learning methods are professional interest, non-standard nature of educational and cognitive activities, competitiveness, playful nature of classes, emotionality, problems, which in combination motivates students and encourages them to actively participate in learning ${ }^{2}$.

We agree with the opinion of the authors of the publication ${ }^{3}$ that the methods of activating educational and cognitive activities effectively affect the learning outcome, as well as encourage teachers to constantly seek innovation and professional growth.

Methods of active learning are of interest to teachers and other professionals in the field of education. Analysis of scientific and methodological literature on the problem of research showed that the problem of using active learning methods in the educational process of higher education is devoted to several studies in psychology and pedagogy,

${ }^{1}$ Райковська Г. О. Формування професійних компетентностей у ВТНЗ шляхом індивідуалізації освітнього процесу. Молодь і ринок. 2016. № 3(134). С. 13-17.

2 Ягупов В. В. Педагогіка : навчальний посібник. Київ : Либідь, 2002. 560 с.

${ }^{3}$ Dytfeld K., Smółka E. metody aktywizujące jako system motywowania uczniów do nauki / katarzyna dytfeld ewelina smółka. Projekt „kompetencje zawodowe nauczycielek i nauczycieli jako element budowania organizacji uczącej się ilokalnej strategii oświatowej wpowiecie ostrzeszowskim" współfinansowany ześrodków unii europejskiej w ramach europejskiego funduszu społecznego. URL: http://www.powiatostrzeszowski.pl/asp/pliki/ dok/publikacja_na_strone_p._katarzyny_dyfteld_i_p._eweliny_smolki.pdf. 
but scientists are quite ambiguous in interpreting the concept of «active learning methods» (table 1).

Table 1

Interpretation of the concept of "methods of active learning"

\begin{tabular}{|l|l|l|}
\hline № & \multicolumn{1}{|c|}{ Author } & \multicolumn{1}{c|}{ Interpretation } \\
\hline 1. & L. Naumov & $\begin{array}{l}\text { methods in which the student is forced to actively extract, } \\
\text { process and implement educational information, which is } \\
\text { presented in such a didactic form that it provides objectively } \\
\text { significantly better, compared to traditional methods, the } \\
\text { results of practical training }\end{array}$ \\
\hline 2. & A. Smolkin & $\begin{array}{l}\text { a way to intensify the educational and cognitive activities of } \\
\text { students, which encourage active mental and practical activities } \\
\text { in the process of mastering the material, when not only the } \\
\text { teacher is active, but also students }\end{array}$ \\
\hline 3. & V. Yahupov & $\begin{array}{l}\text { a set of techniques and methods of psychological and } \\
\text { pedagogical influence on students, which are aimed at the } \\
\text { development of creative independent thinking, activation of } \\
\text { cognitive activity, the formation of creative skills and abilities } \\
\text { of non-standard solution of certain professional tasks }{ }^{6}\end{array}$ \\
\hline 4. & I. Hapeieva & $\begin{array}{l}\text { ways of organizing educational activities that enhance } \\
\text { cognitive motivation, skills and abilities of students to solve } \\
\text { theoretical and practical problems? }\end{array}$ \\
\hline 5. & $\begin{array}{l}\text { E. Hrudzynska, } \\
\text { W. Maryko }\end{array}$ & $\begin{array}{l}\text { methods that stimulate the cognitive activity of pupils and } \\
\text { students, built in a dialogical form, provide a free exchange of } \\
\text { views on ways to solve a problem and are characterized by a } \\
\text { high level of activity }\end{array}$ \\
\hline 6. & N. Navolokova & $\begin{array}{l}\text { methods and techniques of pedagogical influence that } \\
\text { encourage students to mental activity, creative, research } \\
\text { approach and search for new ideas to solve various problems of } \\
\text { educational and research activities? }\end{array}$ \\
\hline
\end{tabular}

The analysis of the concepts given in the table gives the basis to conclude that the characteristic features of methods of active training are:

${ }_{5}^{4}$ Наумов Л. Б. Учебные игры в медицине. Ташкент : Медицина, 1986. 320 с.

5 Смолкин А. М. Методы активного обучения. Москва : Высшая школа, 1991. $176 \mathrm{c}$.

${ }^{6}$ Ягупов В. В. Педагогіка : навчальний посібник. Київ : Либідь, 2002. 560 с.

7 Гапеева И. В. Классификация методов активного обучения иностранным языкам в неязыковых вузах. Проблеми сучасної педагогічної освіти. 2013. Вип. 40(1) Педагогіка і психологія. С. 63-68.

${ }^{8}$ Грудзинская Е. Ю., Марико В. В. Активные методы обучения в высшей школе. Учебно-методические материалы по программе повышения квалификации «Современные педагогические и информационные технологии». Нижний Новгород, 2007. $182 \mathrm{c}$.

${ }^{9}$ Наволокова Н. П. Енциклопедія педагогічних технологій та інновацій. Харків : Основа, 2009. 154 с. 
- increase of educational and cognitive activity of students in the learning process;

- acquisition of skills and abilities through activities in the process of solving tasks;

- imitation of independent scientific research to obtain new skills, which increases the degree of emotionality of students in the learning process;

- involvement of students in active communication in the learning process, resulting in constant interaction of participants in the learning process, the free exchange of views on solving a problem.

The selected features that are inherent in active learning can reduce certain shortcomings that arise in the process of training future specialists in technical specialities, identified and substantiated by us in publications ${ }^{10,11,12}$ :

- inconsistency of the studied material with the expectations of students and their ideas about the future professional activity;

- insufficient connection between theoretical material and practice;

- lack of motivation to study occupational safety disciplines, which are the foundation of the formation of occupational safety competence;

- excessive complexity or simplicity of the material;

- monotony of presentation of lecture material, which is not accompanied by examples, clarity, problem elements, etc.

However, in this aspect, it should be taken into account that it is impossible to divide the methods into active and passive because by using different methods of activating educational and cognitive activities, we increase student activity in learning.

Examples are a classic lecture with elements of discussion, conducting a seminar using some problematic aspects, using situational exercises during practical classes, improving the content of the laboratory lesson with the inclusion of innovative issues in a particular field, and so on.

In this context, the opinion of $\mathrm{O}$. Vyshnevskyi is relevant that the concept of «passivity-activity» in the classifications of teaching methods is quite relative. After all, in real learning conditions, we can not talk about

10 Дембіцька С. В. Організація самостійної роботи студентів 3 безпеки життєдіяльності в процесі підготовки фахівців. Педагогіка безпеки. 2016. № 1(1). С. $48-52$.

11 Дембіцька С. В. Педагогічні умови формування культури охорони праці в процесі підготовки фахівців. Сучасні інформачійні технологій та інноваційні методики навчання у підготовці фахівців: методологія, теорія, досвід, проблеми. 2014. Вип. 37. С. 382-387.

12 Дембіцька С. В., Кузьменко О. С. Формування професійного мислення студентів технічних вузів у процесі вивчення фізики. Педагогічні науки. 2016. Вип. LXXI. T. 1. C. 43-47. 
their absolute presence or absence, but only about a certain ratio, which is solved differently in certain learning conditions ${ }^{13}$. The main task of a high school teacher is to find the optimal ratio of methods and means of teaching, which will effectively solve the pedagogical task.

At the present stage of development of higher education, scientists are searching for and implementing in the educational process innovative methods of active learning, which allow motivating students to study a particular discipline.

One of such innovative technologies is open space technologies. If we turn to history, it is believed that the first event in the format of Open Space took place in 1985 during the Third International Symposium on Organizational Transformation in Monterey (California, USA). Since then, this method has been used effectively in many countries around the world for meetings, consultations and meetings.

For example, with the help of this technology, Boeing developed a fundamentally new design of the aircraft door, and the American telephone company AT\&T designed the pavilion for the 1996 Olympic Games in Atlanta $^{14}$. And many such examples confirm the effectiveness of this technology, especially in technical fields. In Ukraine, Open Space technology has been used for over 10 years.

Analysis of the peculiarities of the use of the studied technology in Ukraine and the world showed that it shows the most significant results during:

- stakeholder consultations;

- search for organizational solutions in times of uncertainty;

- search for creative solutions, research and development;

- solving technical problems;

- exchange of views on a particular issue or problem;

- project planning;

- joint search for new ideas and solutions.

Such results regarding the introduction of Open Space technology allowed to make assumptions about the effectiveness of this technology during the diploma design and research work of students. We will substantiate our decision. Usually, the direction for scientific work that will further determine the subject of his bachelor's and master's theses, students receive from the teacher without taking into account his preferences. This reduces the student's interest and turns scientific work into work that is carried out under duress «because» it is necessary.

13 Вишневський О. I. Теоретичні умови сучасної української педагогіки : посібник. Дрогобич : Коло, 2003. 326 с.

14 Лабода C. Технология Open Space, или Чудеса кофе-паузы в «открытом пространстве». Адукатар. 2005. № 2(5). С. 18-23. 
Preliminary consultations with students in the format of Open Space allows not only each of them to choose the most interesting area of research, but also to characterize possible areas of research based on the generalization of all ideas formulated by participants in this area.

It is possible to additionally perform the following tasks:

- to consider and generalize the most important directions relevant for further scientific research;

- to practice the skills of discussion, teamwork.

\section{Methodological features of the use of Open Space technology in the process of professional training in a higher education institution}

The seminar in the format of Open Space, the purpose of which is to choose the direction of the scientific work of the student is conducted as follows. The event begins with a greeting from all participants. The role of the coordinator is played by a teacher who is familiar with the features of the technology. Its first task is to acquaint everyone with the rules of the Open Space, its main principles and methods of work of the participants. After such an introduction, all those who wish to become organizers of separate working groups have the opportunity to outline on paper the direction (within the general theme) that interests them most. As a rule, the role of such organizers is played by the most active students who are oriented in the research field. It is known that the student audience is quite diverse in terms of knowledge and motivation for scientific work, so this approach allows you to unite a working group around a particular leader.

Then, in turn, everyone voices the topic or direction they have identified and invites those who want to join the discussion. In the process of such a discussion, the real topic of the research project is outlined, ideas for development are put forward, which will then come in handy. In this case, it is advisable to record the discussion. For example, the board is divided into several departments, in which the process is recorded, such as novelty, areas for improvement, feasibility, and so on.

As the practice of conducting experimental seminars in the format of Open Space at Vinnytsia National Technical University has shown, in the process of such work several scientific directions of research are formed. At the same time, each student joins the group that he considers more interesting and promising. Making a choice independently and consciously, in the future the student is responsible for the task.

The next stage is the work of interest groups, discussion of further actions. Each group summarizes its work in the form of a protocol in the prescribed form. At the same time, it should be formed clearly, with a reasonable plan for further work for each participant. In the future, the final discussion of the work done is also in the format of open space. 
Each of the participants reports in any form the results obtained, which are discussed by members of the whole group. In the process of such work, the possible disadvantages, advantages are indicated and the final result is outlined.

An approximate plan for such an event is as follows:

1. Acquaintance of participants. Announcement of general scientific topics, within which the discussion will be carried out, the rules of the event, the purpose and objectives of the meeting.

2. Participants who wish to be organizers of working groups, voice ideas on areas of research. There is a brief discussion of the features of the voiced topic and the place and time where the meeting of the interest group will take place.

3. Working groups are being formed. Each student joins the group he or she finds most interesting.

4. Discussion is carried out in working groups. At the same time, it is possible to transfer participants to other groups to compare areas of research.

5. Summarizing the results within the group with the subsequent registration of the protocol and presentation of the results.

The analysis of carrying out of actions with the use of technology of Open space gives the bases to consider as criteria of expediency of introduction of researched technology during the organization of scientific work of students the following:

- the complexity of the task, the obvious need to deepen its understanding or outline the expected results;

- the presence of various problematic aspects of the outlined topic, which creates the need to involve a significant number of participants in the search for appropriate solutions;

- urgency and urgency to solve a problem.

To determine the appropriateness and effectiveness of the use of Open Space technology in the performance of students' research work, a chamber pedagogical experiment was conducted. In this regard, Vinnytsia National Technical University and the Flight Academy surveyed teachers on the use of active learning methods, the results of which are shown in fig. 1. A total of 34 people took part in the survey, all respondents have academic degrees and are lecturers. 


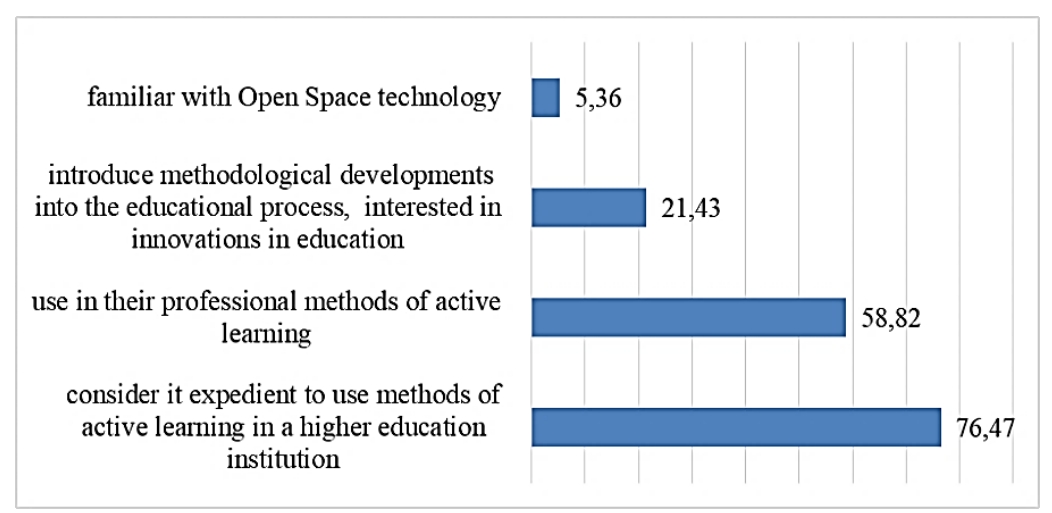

Fig. 1. The results of a survey of teachers on the use of active learning methods in free economic education

As can be seen from fig. 1, the majority of respondents consider it expedient to use methods of active learning in the process of professional training of future specialists in technical specialities, with $58.85 \%$ using them in their own pedagogical activities. The share of those who implement their own experience and adapt the existing pedagogical experience to the conditions of a particular speciality and group is $21.43 \%$, and the share of those who are familiar with Open Space technology - only $5.36 \%$ of respondents or 3 people. At the same time, a conversation was held with those who showed awareness of the studied technology and it turned out that they took part in activities conducted by Open Space technology, but attempts to use it in the training of students have not yet been made.

Analysis of the results of a survey of students (a total of 126 people) about the effectiveness of active learning methods showed the following results (fig. 2). 


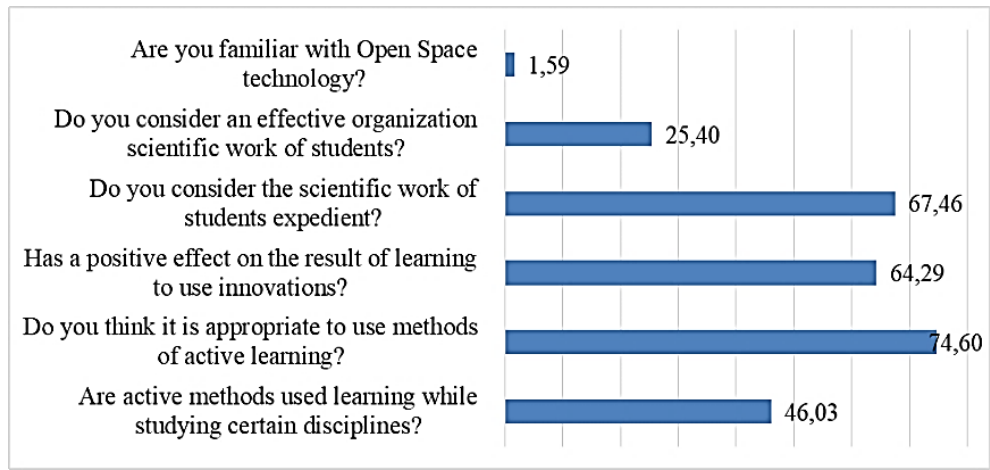

Fig. 2. The results of a survey of students on the use of active learning methods in free economic education

The results of the survey of students showed that students consider the use of innovations in the study of academic disciplines to be positive, but only $46.03 \%$ of respondents indicated that such methods are used. $67.46 \%$ believe that scientific work is necessary and appropriate, because the result of modern higher education should be not only a certain level of knowledge, skills and abilities, but also formed skills to perform scientific tasks, the ability to analyze phenomena, forecast trends and skills of self-education. However, only $25.40 \%$ of students believe that the modern organization of scientific work of students is appropriate and effective. $1.59 \%$ or 2 of all respondents are familiar with the technology of Open Space, however, as in the previous case, took part in various activities outside the free economic zone, which were conducted using this technology.

Then a chamber pedagogical experiment was organized to test the effectiveness of the organization of scientific work of students using the technology of Open Space. It should be noted that, despite the interest of scientists in the methodological support and organization of scientific work of students, there are no clear criteria for its effectiveness. Therefore, based on our own experience, covered in the publications ${ }^{15,16}$ criteria for the

15 Дембіцька С. В., Кобилянский О. В. Організація науково-дослідної роботи студентів в процесі вивчення дисципліни «Охорона праці». Збірник наукових прачь Кам'янеиь-Подільського національного університету імені Івана Огієнка. Серія педагогічна. 2015. Вип. 21. С. 191-194.

16 Дембіцька С. В., Кобилянский О. В. Особливості організації науководослідної роботи студентів у процесі вивчення дисципліни «Охорона праці». Дидактика фізики як концептуальна основа формування компетентнісних $i$ світоглядних якостей майбутнього фахівия фізико-технологічного профілю: збірник матеріалів X Міжнародної наукової конференції. Камянець-Подільський : Рута, 2015. С. 96-98. 
effectiveness of the organization of independent work, we choose the following:

- number of scientific articles published by students;

- number of abstracts published by students at conferences;

- number of prepared scientific works of the university and All-Ukrainian level;

- average grade of defence of qualification (bachelor's and master's theses).

The chamber pedagogical experiment, which lasted for one academic year, was attended by 45 students of Vinnytsia National Technical University and 21 students of the Flight Academy of the National Aviation University of the fourth year of bachelor's degree. The total number is 66 people. A control and two experimental groups were formed so that they had approximately the same number of individuals. Students of Vinnytsia National Technical University were united into 1 control and 1 experimental group of 23 and 22 people, respectively, students of the Flight Academy - formed an experimental group.

Students of the control group carried out scientific work under the guidance of teachers according to traditional methods, students of the experimental group were involved in activities in the format of Open Space monthly during the school year to solve problems that arise during research and reporting. The first such meeting according to the method described above was held to determine the direction of scientific work, the other working meetings - to correct the results. An additional advantage of this approach is that it does not require time to organize such meetings. Unlike other innovative pedagogical methods, which provide a thorough preparation of the teacher for the activities, the functioning of the technology of Open Space is ensured by self-organization of students.

The result of the chamber pedagogical experiment in quantitative terms is shown in fig. 3 , per 1 student - in fig. 4 .

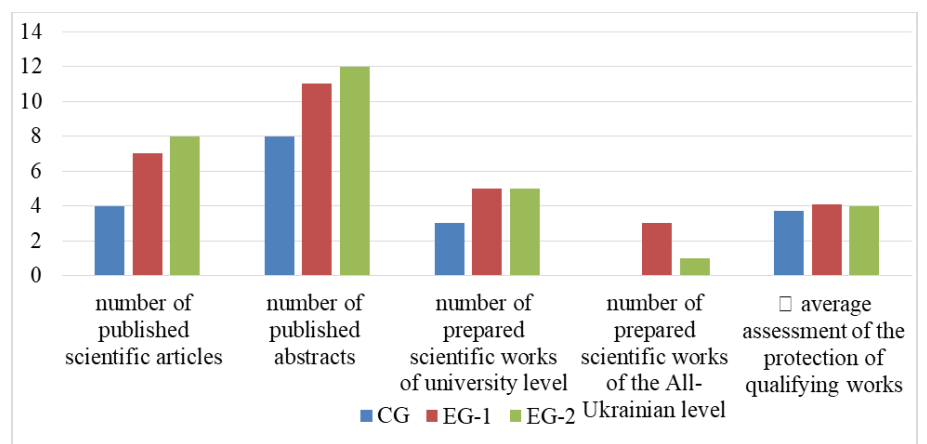

Fig. 3. The results of the chamber pedagogical experiment (in quantitative terms) 


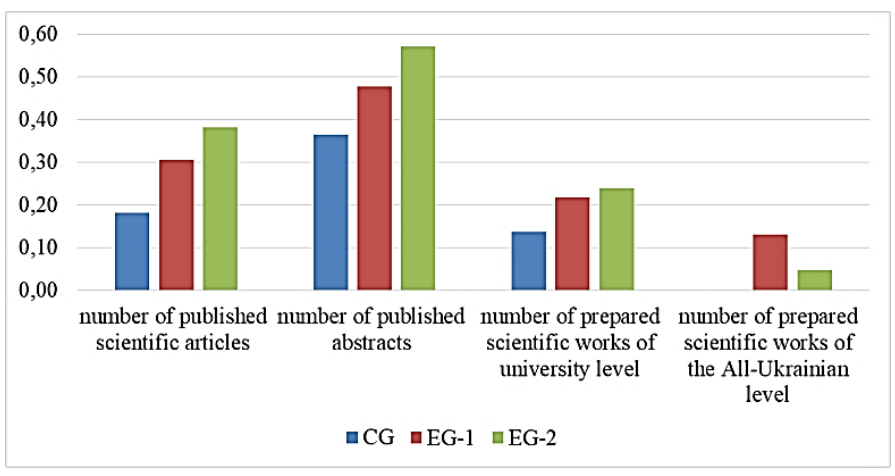

Fig. 4. The results of the chamber pedagogical experiment (per student)

As shown in fig. 3 and fig. 4, the students of the experimental groups showed higher performance of scientific work. Analysis of the protection of bachelor's theses of students of control and experimental groups shows that the average assessment of the protection of qualifying works for experimental groups is higher than for the control. In particular, for the control group, this figure is 3.6 points (on a five-point scale), for students in the experimental groups -4.1 and 4.0 , respectively.

For the further organization of the pedagogical experiment it is necessary:

- to involve students of different courses in experimental work to determine the impact of the proposed innovations in different conditions;

- to eliminate the shortcomings revealed in the course of carrying out of experiment concerning the organization of scientific work of students;

- to develop clear criteria for the effectiveness of the organization of scientific work of students. The criteria used by us are quantitative and do not allow us to fully assess the quality of scientific work by students;

- based on the specified criteria of efficiency of the organization of scientific work of students, to develop the accurate mathematical device of an estimation of results of the spent experiment which will allow establishing statistical significance of the received indicators.

\section{CONCLUSIONS}

Thus, active learning methods are an effective tool in the process of training specialists in freelance, as they allow not only to ensure effective mastery of a certain system of knowledge and skills but also to develop creative skills, generate new ideas and concepts, the teacher to grow professionally with students. 
The article was an attempt to summarize the experience gained in the use of open space technology in the training of future specialists in technical specialities. It was substantiated that such technology is the most effective for improving the organization of scientific work of students because it allows them to independently choose the trajectory of their scientific research and thus form a positive motivation for its implementation.

In comparison with the traditional form of organization of the research work of students, the innovative approach tested by us allows them to independently predict the results of their scientific work. Realizing their responsibility for learning outcomes, students discuss the outlined topics of scientific research, carry out joint planning of activities, outline ways to implement the problem. During meetings in the Open Space format, it is possible to get tips on a problem that has arisen on the way to a certain task or even to make a fundamentally new discovery. The results of the survey and the chamber pedagogical experiment showed the effectiveness of the proposed technique compared to traditional but also revealed a number of shortcomings that need to be addressed.

In particular, such shortcomings include the inability to discuss, the rejection of the discussion in the personal plane, the reluctance of individual students to participate in innovative activities, the reluctance of individual teachers to change the mode of their work and so on. Besides, methodological recommendations for the organization of student's scientific work through the use of Open Space technology and a list of criteria for evaluating the results of student's scientific work require refinement and developed.

A more detailed study of innovative technologies for the organization of scientific work of students in a comparative aspect with the results obtained in the process of using the technology of Open Space seems promising.

\section{SUMMARY}

The relevance of the researched problems is that the use of active learning methods in the process of professional training of future specialists is a requirement of time.

Accordingly, there is a need to develop guidelines for their implementation in the educational process, taking into account the peculiarities of higher education. The work aims to study the possibility of using the technology of Open Space in the process of training specialists in technical specialities, as well as to find conditions for its implementation in the educational process of higher education institutions.

The article summarizes the peculiarities of the use of active learning methods in free economic education and describes the theoretical aspects of the use of Open Space technology in higher education institutions. The method of organizing the scientific work of students by using the technology 
of Open Space was proposed and a plan of such an event was developed. A chamber pedagogical experiment was conducted, which confirmed the effectiveness of the proposed method and made it possible to identify its shortcomings for such work.

We consider promising a detailed study of existing innovative technologies for the organization of scientific work of students in a comparative aspect with the results obtained in the process of using the technology of Open Space.

\section{REFERENCES}

1. Dytfeld K., Smółka E. metody aktywizujące jako system motywowania uczniów do nauki / katarzyna dytfeld ewelina smółka. Projekt „kompetencje zawodowe nauczycielek i nauczycieli jako element budowania organizacji uczącej się ilokalnej strategii oświatowej wpowiecie ostrzeszowskim" współfinansowany ześrodków unii europejskiej w ramach europejskiego funduszu społecznego. URL: http://www.powiatostrzeszowski.pl/asp/pliki/dok/publikacja_na_strone_p._k atarzyny_dyfteld_i_p._eweliny_smolki.pdf.

2. Вишневський О. I. Теоретичні умови сучасної української педагогіки : посібник. Дрогобич : Коло, 2003. 326 с.

3. Гапеева И. В. Классификация методов активного обучения иностранным языкам в неязыковых вузах. Проблеми сучасної педагогічної освіти. 2013. Вип. 40(1) Педагогіка і психологія. С. 63-68.

4. Грудзинская Е. Ю., Марико В. В. Активные методы обучения в высшей школе. Учебно-методические материалы по программе повышения квалификации «Современные педагогические и информационные технологии». Нижний Новгород, 2007. 182 с.

5. Дембіцька С. В. Організація самостійної роботи студентів 3 безпеки життєдіяльності в процесі підготовки фахівців. Педагогіка безпеки. 2016. № 1(1). С. 48-52.

6. Дембіцька С. В. Педагогічні умови формування культури охорони праці в процесі підготовки фахівців. Сучасні інформачійні технологій та інноваційні методики навчання у підготовиі фахівців: методологія, теорія, досвід, проблеми. 2014. Вип. 37. С. 382-387.

7. Дембіцька С. В., Кобилянский О. В. Організація науководослідної роботи студентів в процесі вивчення дисципліни «Охорона праці». Збірник наукових праць Кам'янець-Подільського національного університету імені Івана Огієнка. Серія педагогічна. 2015. Вип. 21. C. 191-194.

8. Дембіцька С. В., Кобилянский О. В. Особливості організації науково-дослідної роботи студентів у процесі вивчення дисципліни «Охорона праці». Дидактика фізики як конщептуальна основа 
формування компетентнісних $і$ світоглядних якостей майбутнього фахівия фізико-технологічного профілю : збірник матеріалів Х Міжнародної наукової конференції. Камянець-Подільський : Рута, 2015. С. 96-98.

9. Дембіцька С. В., Кузьменко О. С. Формування професійного мислення студентів технічних вузів у процесі вивчення фізики. Педагогічні науки. 2016. Вип. LXXI. Т. 1. С. 43-47.

10. Лабода C. Технология Open Space, или Чудеса кофе-паузы в «открытом пространстве». Адукатар. 2005. № 2(5). С. 18-23.

11. Наволокова Н. П. Енциклопедія педагогічних технологій та інновацій. Харків : Основа, 2009. 154 с.

12. Наумов Л. Б. Учебные игры в медицине. Ташкент : Медицина, 1986. $320 \mathrm{c}$.

13. Райковська Г. О. Формування професійних компетентностей у ВТНЗ шляхом індивідуалізації освітнього процесу. Молодь і ринок. 2016. № 3(134). C. 13-17.

14. Смолкин А. М. Методы активного обучения. Москва : Высшая школа, 1991. $176 \mathrm{c.}$

15. Ягупов В. В. Педагогіка : навчальний посібник. Київ : Либідь, 2002. $560 \mathrm{c}$.

Information about the authors: Dembitska S. V.,

Doctor of Pedagogical Sciences, Associate Professor, Professor at the Department of Life Safety and Safety Pedagogy

Vinnytsia National Technical University 95, Khmelnytske shose str., Vinnytsia, 21021, Ukraine

Kuzmenko O. S.,

Doctor of Pedagogical Sciences, Associate Professor, Professor at the Department of Physics and Mathematics Disciplines

Flight Academy of the National Aviation University 1, Dobrovolskoho str., Kropyvnytskyi, 25005, Ukraine 